\title{
Long-Term Performance Implications of Management Innovation*
}

\author{
Muamer Bezdrob**
}

\begin{abstract}
Any kind of innovative activity is driven by the urge for utmost success, continuous improvement or mere survival. The same holds true for management innovation, arguably the most advanced innovation type in the world of business. Although previously unjustifiably neglected, a significant number of studies have emerged recently that prove the potency of this type of innovation. Following such a trend, this study explores another distinguishing feature of management innovation - its durability. The study findings confirm the claim that companies that are innovative in management achieve better business performance in the long run. In addition, the study provides further support for the new direction in researching the innovation concept - an interdependent or synchronous approach to the adoption of different types of innovation on the company level.
\end{abstract}

Keywords: Management Innovation, Business Performance, Long-term, Bosnia and Herzegovina

\section{Introduction}

Running a business in the modern world of fierce competition is unthinkable without the persistent development of sustainable competitive advantages. Ever since the early years of the $20^{\text {th }}$ century scholars have argued that innovation is one of the main drivers of economic changes (Schumpeter 1939). Following that line of thought, management practitioners and scholars alike hold a strong belief that innovations represent a critical source of competitive advantage and, consequently, company performance (Crossan/Apaydin 2010). Even though this propensity is primarily associated with the technological innovations, recent research extends it to the non-technological innovations as well (Damanpour 2014).

The outcomes of management innovation process are complex and manifold in their impact, because a great number of stakeholders are involved or affected by different phases of the process (Birkinshaw/Hamel/Mol 2008). One set of particularly important outcomes is, definitely, the impact of management innovation on company performance, which is, arguably, more potent and durable than any other type of innovation (Hamel 2006, 2007).

When I first set out to do research on management innovation, almost ten years ago, there were but a few empirical studies analysing the relationship between

* Received: 10.01.2018, accepted: 04.04.2018, 1 revision.

** Muamer Bezdrob, PhD, Assistant professor, American University in Bosnia and Herzegovina, Sarajevo, E-mail: mbezdrob@aubih.edu. Main research interests: management innovation and management development. 
this type of innovation and company performance (Birkinshaw et al. 2008). Since then, a number of studies related to many different aspects of the management innovation concept emerged, primarily through the works of Hamel, Birkinshaw, Mol, Damanpour, and Walker, but also many other scholars. Accordingly, nowadays one can find numerous studies on the relationship between management innovation and company performance (see Damanpour 2014 and Walker/ Chen/Aravind 2015).

All these studies (e.g. Damanpour/Walker/Avellaneda 2009; Walker/Damanpour /Devece 2011; Bezdrob/Šunje 2012; Sapprasert/Clausen 2012) undoubtedly point to the positive link between management innovation and company performance. However, no study tends to compare the potency of management innovation and innovation of any other type. The same holds true for the comparison of durability of innovation.

Assuming such a factual situation, this study was conceived to empirically test the above claims about management innovation durability, and hence provide a deeper insight into the issue. More specifically, it aims to quantitatively explore the long-term performance of managerially innovative companies and, subsequently, compare it with the long-term performance of non-innovative companies. Thus, the basic research question of this study is as follows:

RQ: Do managerially innovative companies achieve higher long-term business performance than non-innovative companies, and, if they do, whether such a performance difference increases with time?

This research question outlines the purpose and scope of this study. Appropriate hypotheses were devised on that basis and, subsequently, a corresponding research design was adopted. The data analysis was done on a sample of companies that are registered in the Federation of Bosnia and Herzegovina.

The following section provides a review of literature related to management innovation and ends with a list of research hypotheses that will be subsequently tested. The third section describes the data and research design, as well as the method used in empirical data analysis. The section ends with a detailed report and discussion about the obtained results. Finally, the paper finishes with some concluding remarks about the study.

\section{Literature Review}

Although several authors have previously studied the management innovation phenomenon (Gruber/Niles 1972, 1974; Stata 1989; Abrahamson 1991; Damanpour 1991), only after initial works of Hamel, Birkinshaw and Mol on this topic (Birkinshaw/Mol/Hamel 2005; Birkinshaw/Mol 2006; Hamel 2006, 2007), was more attention towards this very important type of innovation created within the 
academic community. Gary Hamel's book "Future of Management" (2007) was of a particular importance for the advancement of studies on management innovation. In this book, Hamel, in his distinctive way, invokes and encourages both management theorists and practitioners to invent a new management concept for the $21^{\text {st }}$ century. Most recent works of Fariborz Damanpour provide a comprehensive overview of the current understanding and perspective on research into management innovation (Damanpour/Aravind 2012, Damanpour 2014).

Relying on the theory set up by these scholars, and in particular on Gary Hamel's work, this study deals with management innovation as, perhaps, one of the most important competitive advantages of a company, and, ultimately, superior business performance in the long run.

\subsection{Management Innovation - The Definition}

Arguably, the most important process in any business organization is how such organization is managed, that is which management model is employed. Furthermore, adjusting such management model to the ever-changing business environment is of paramount importance to all modern companies, not only to the successful operations, but even for the very existence (De Witt/Meyer 2014). The managerial practices and procedures that enable this adjustment, called management innovation, keep the business currently successful and, more importantly, enable a sustainable competitive advantage over a longer period of time (Hamel 2006).

Very often, the term innovation is treated interchangeably with the term invention. The latter term is related to the act of designing something that previously did not exist, while innovation relates to the implementation of previously created ideas. First to make the distinction between these two terms was Joseph Schumpeter in his theory of innovation (Schumpeter 1939). He recognized innovations as a critical driver of economic change, while the inventions are outside and beyond the field of economics (Shaw Solo 1951).

Later on, many other authors offered their definitions of (different types of) innovations (Damanpour 1992; Hargrave/Van de Ven 2002; Crossan/Apaydin 2010), but in each of these definitions one can find two important determinants of the innovation concept - "change" and "novelty". Thus, in this study, the following definition of innovation is used:

Changes or modifications made to the form, quality or status, of any system, behaviour, structure, process, product or service of an innovative organization, where such a change or modification makes a completely new or significant shift from the previous state.

This definition brings a very important determining factor about comprehension of innovation concept. Specifically, definition states that changes or modifications can produce a completely new state or cause a significant shift from the 
previous state, and innovations relate to both outcomes. This is important because there exist two approaches to defining management innovations (Mol/ Birkinshaw 2009). According to the first approach, management innovation assumes only those practices, tools or structures that have never been introduced or used before (i.e. new to the state-of-the-art). The other approach refers to those management innovations that are new to a particular business organization, and are adapted from another context (for example, practices and/or structures previously introduced in a similar organization). Innovation that is completely new to the world is quite rare (Hamel 2006), and can be conceived only by a small number of innovative firms. Thus, in this study, the second approach to defining management innovation is adopted.

Based on previous reasoning, and relying on the definition given by Mol and Birkinshaw (2007), the management innovation definition that fits the research goals in this study can be stated as follows:

Management innovation is an implementation, change or adaptation of managerial practices, processes, tools and/or structures, where such implementation, change or adaptation makes a completely new or significant shift from the previous situation, intended for improving the organization's business performance.

Decomposing this definition into its constituent parts, one can find the answers to three key issues related to the concept of management innovation (Birkinshaw et al. 2008): 1) what is being innovated; 2) how "new" innovation needs to be; and 3) what is the purpose, or the ultimate goal of management innovation?

First, the statement of "managerial practices, processes, tools and/or structures" refers to all managerial activities that managers undertake (Hamel 2006). This indicates that the implementation, change or adaptation of any activity that managers do can be considered as a management innovation, which provides a direct answer to the first key issue of the management innovation concept.

Second, in response to another key issue, the operational definition of management innovation clearly indicates that innovation does not have to be completely new to the world, but "only" new to the organization which implements it.

The third critical element of the definition - the goal of improving the organization's business performance, is the primary reason why innovative organizations generally engage in the innovation process and accept all the risks that the process brings (Birkinshaw et al. 2005).

As Hamel argues that management innovation can make a drastic improvement in company's competitive position and, consequently, produce long-lasting business performance (Hamel 2006), it is this inseparable connection between management innovation and business performance that is of main interest for this study, with a particular emphasis on performance durability. 


\subsection{Management Innovation - The Effects}

Measuring the strength and direction of influence, or assessing the consequences of introducing any kind of innovation is a difficult task. However, it is a common belief that innovation is important for performance, competitive advantage and business success (Stock/Zacharias 2011; Damanpour 2014). In addition, the improvement of managerial practices contributes to increasing the productivity and competitive advantage of a company, and thus improving the macroeconomic performance (Birkinshaw et al. 2005).

From the available literature (Crossan/Apaydin 2010) it is easy to recognize that the main reasons for the company to engage in uncertain and risky process of innovation are: 1) solving serious organizational problems, and even the survival of the company (Land 1973), 2) advancing competitive position (e.g. Helfat et al. 2007), and 3) improving business performance (e.g. Mol/Birkinshaw 2009). Although at first glance these three reasons describe very similar organizational drivers, there is a significant difference between them. While the first driver of innovative activities is the question of the mere existence of company, the second and third reasons are related to the issues of company's effectiveness and efficiency, respectively. Whatever the reason is, innovation is one of the most important aspects of modern business.

On the other hand, the company's welfare is the primary goal of the effective managers, and all the actions and activities they do are in the best interests of the company (Drucker 1974). Combining that with the fact that all the major management innovations came not from academic laboratories or hypothetical environments, but from really innovative business organizations (Hamel 2006), one can conclude that the effects of introducing management innovations are clearly and undoubtedly on the line of advancing the success of innovative organization.

Indeed, even the superficial analysis of some examples points toward the importance and effect size of management innovation:

- Taylor's and Fayol's principles of management represent the foundation of modern management (Weihrich/Koontz 1994) - establishing the fundamental principles of managing business organizations.

- The introduction of the industrial research laboratory by General Electric still represents the basis of the competitive position of this industrial giant (Hamel 2006) - establishing a long-lasting competitive position.

- The divisional structure (M-Form), introduced by General Motors, is the dominant organizational structure for large diversified companies (Chandler 1962) - providing a solution to complex and critical management problems.

- Employee empowerment in order to increase the efficiency and quality of products launched by Toyota Corporation led this company to the industry leader position worldwide (Spear/ Bowen 1999) - providing necessary con- 
ditions for improvement of or directly increasing the performance of a business organization.

Last but not least, two important features of management innovation need to be emphasized - durability and potency. As Hamel (2006; 2007) asserts, the positive effect of management innovation provides a powerful advantage to an innovative company and lasts much longer than is the case with any other type of innovation, including the most significant technological breakthroughs.

\subsection{Management Innovation - Impact on the Long-term Performance}

Academic circles have started pointing to the strong link between innovative activities (causes) and improvements in business performance (effect) since the early years of the $20^{\text {th }}$ century. All competent groups - managers, policy makers, and academics agree on the importance of innovation, both on macro (macroeconomic growth) and micro (company performance) level (Damanpour 2014). The latter impact domain is of particular interest, since the main goal of this study is to explore the relationship between management innovation and business performance in the long run.

A number of studies support the presence of a positive link between innovation and business performance (Porter 1990; Klomp/van Leeuwen 2001; Stock/ Zacharias 2011), but the emphasis in these studies is mainly on technological innovation. Nevertheless, recently have been a number of empirical studies confirming positive contribution of management innovation to the company performance (Damanpour 2014; Walker et al. 2015). In these studies, both management innovation and performance is measured in many different ways, but measurement period is usually short-term (Mol/Birkinshaw 2009; Walker et al. 2011; Nieves 2016) or mid-term (Bezdrob/Šunje 2012; Sapprasert/Clausen 2012; Hervas-Oliver/Ripoll-Sempere/Moll 2016).

All these results support the claims of the positive impact of management innovation on business performance. However, the main goal of this study is to test the claim of potency and, in particular, durability of management innovation. Although there are no empirical studies of the long-term effect of innovation, many cases from the real-world companies strongly support such a claim (Hamel 2006, 2007). In order to address this issue correctly, an appropriate testing model and accompanying research design should be established.

As the first step in implementing this testing model, the long-term business performance of the innovative and non-innovative companies should be compared. Accordingly, the first hypothesis of this study is:

H1: The business performance of innovative companies in a long run is higher than that of non-innovative companies. 
A favourable outcome of testing the first hypothesis can be considered as satisfying the necessary conditions for management innovation durability. Here, a favourable outcome assumes that the rivalling null-hypothesis ("There is no difference in a long-term business performance between innovative and non-innovative companies.") has been rejected.

For the full support of the main assertion of this study - the potency and durability of management innovation, the performance superiority over time of innovative companies should be assessed. Thus, the second hypothesis is posed as:

\section{H2: $\quad$ The difference between long-term performance of innovative and non-in- novative companies increases with time.}

These two hypotheses define the testing model and determine the corresponding research design, which is presented and described in the following section.

Finally, due attention should be paid to the meaning of the expression "longterm", that is, to provide some answers to the question "How long is longterm?" In the context of this study, the expression "long-term" is related to the length (or duration) of a particular period of time. Determining (or measuring) the length (or duration) of this period of time (expressed in certain time units months, years, decades) depends on the circumstances and context to which the measurement relates.

In accounting, for example, anything longer than one year can be considered as a long-term, while in the investing realm, according to the "BusinessDictionary.com", long-term is a period in which an asset is held for at least seven years. In economics it relates to the period during which a complete adjustment to the changes can be made (Samuelson/Nordhaus 1995), which does not provide any specific duration.

Obviously, "long-term" is not an absolute term, but is defined arbitrarily in any given study in accordance with a specific circumstantial context. Consequently, for this study, "short-term" corresponds to the time period of up to one year, while "long-term" is related to a period of ten or more years. All time-periods whose duration falls between one year and ten years are considered as "midterm".

\section{Data and Methodology}

The study has been conducted through two phases over a six-year period. The first phase was a survey of 320 randomly selected companies that are registered in the Federation of Bosnia and Herzegovina, conducted in 2012. All selected companies comply with the following profile: 
- employing at least 20 people (in any year during the period from 2006 to 2010),

- established in 2002 or earlier,

- privately owned or with mixed ownership (majority private capital),

- not belonging to financial, health care, social welfare, educational or public sector.

The second phase of the study was an archival research of financial reports from the companies that have sent valid responses to the survey, for three time-periods: 2005-2006, 2005-2010, and 2005-2015. Archival research assumed the obtaining of data which are necessary for the assessment of long-term business performance (data from balance sheets and income statements) for the companies whose representatives - top and mid-level managers, completed the survey questionnaires. The data were obtained from the Financial-Intelligence Agency (former Agency for Financial, Information and Agential Services).

A total of 168 responses $(52.50 \%)$ to the survey were received, out of which 143 were valid (44.69\%). However, by 2015, the ending year of the third study timeperiod, nine companies ceased to exist, thus leaving 134 (41.88\%) valid participants in the study.

The estimated population of the companies that comply with the described profile is about 1500 , so the expected statistical error is around $9 \%$ (95\% confidence level). The companies are proportionally distributed among different industries and different geographical parts of the Federation of Bosnia and Herzegovina.

\subsection{Research Design and Measures}

The main concern of this study is the trend of improvement in business performance over different time-periods, and the comparison of such trends between different groups of companies. In order to conduct an appropriate testing, the mixed design with two-way MANOVA was employed. This data analysis technique is especially useful when the group difference on a latent variable needs to be compared across different levels of two independent factors (Verma 2016).

The corresponding research design is presented in Figure 1. Business performance (the latent variable) of randomly selected companies from the target population was evaluated through three different time-periods (within-subject factor): 2005-2006, 2005-2010, and 2005-2015 (factor 2), and then compared on a group level (between-subject factor) - innovative companies vs. non-innovative companies (factor 1). Here, innovativeness is strictly related to the management innovations. 
Figure 1. Layout of the research design

Factor 2-Time-period (TP)

\begin{tabular}{|c|}
\hline Period 1 \\
$2005-2006$ \\
\hline
\end{tabular}
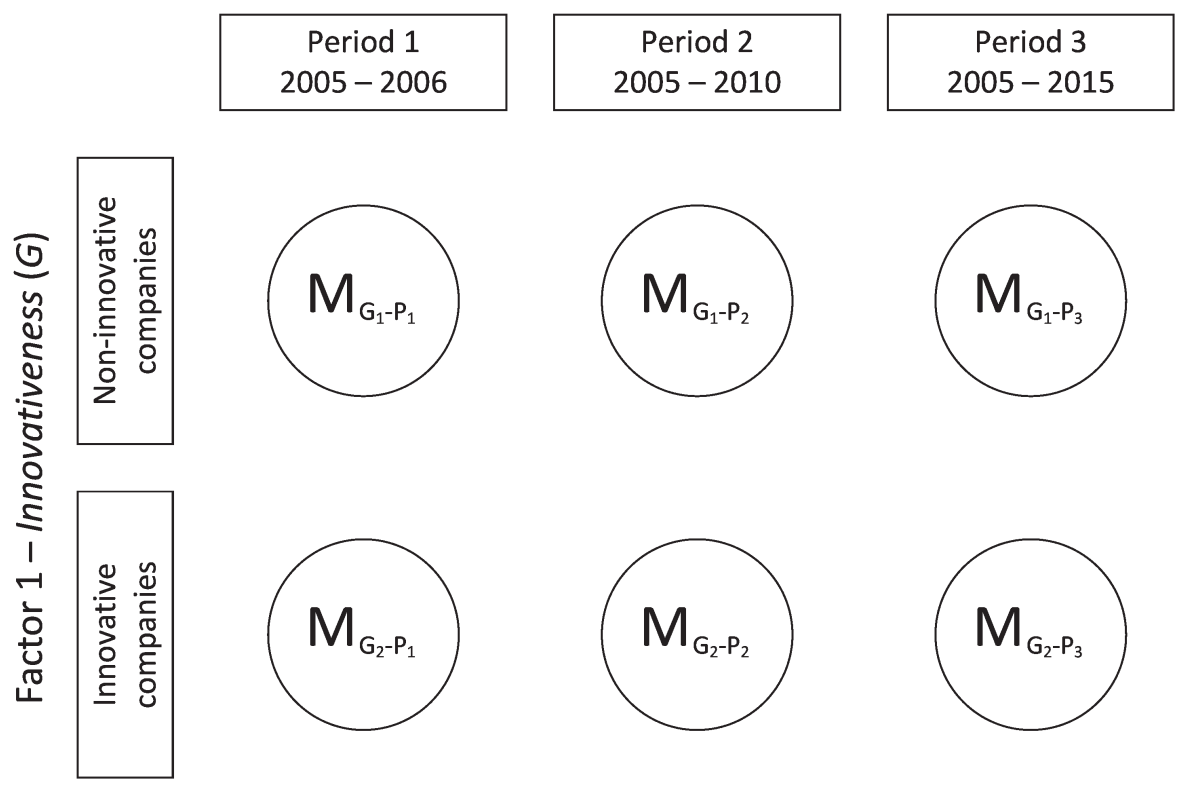

The latent variable, business performance, is measured by three indicators, which are listed and described in the section below. As it can be seen from Figure 1, there are six sets of business performance measures, which are designated with $M_{G} i_{-T P} j(i=1,2 ; j=1,2,3)$. Each measure-set $\left(M_{G} i_{-T P} j\right)$ relates to the single data-cell of the research design matrix, where one dimension of this matrix is defined by the factor 1 - independent variable $G$ (Innovativeness), and the other dimension is defined by the factor 2 - independent variable TP (Time-period)

The independent variable $G$ was measured using data from the survey, while the dependent variable was measured using data from the official balance reports of the corresponding companies. For the independent variable $G$, the measurement spans a five-year period from the year 2006 to the year 2010, while the measurement for the dependent variable spans three time-periods determined by independent variable $T P$ - from the year 2005 to the year 2006, from the year 2005 to the year 2010, and from the year 2005 to the year 2015 .

\subsubsection{Dependent Variables}

Usually, the profitability, measured by some appropriately chosen (key) performance indicator(s), is a determinant of short-term business success, while the growth, in its widest sense, is used as a determinant of long-term business suc- 
cess. Simultaneous business success in short and long-term is the main challenge and ultimate goal of the company's management (Hill/Jones 2013). Thus, the performance measurement and management is of an utmost importance for today's managers (Lebas/Euske 2007).

Traditionally, the measurement of business success relied on the data obtained solely from the financial functions. However, purely financial measurement systems tend to have a short-term view of the company's performance (Neely/ Kennerley/Adams 2007). To overcome this flaw, in the late $1980 \mathrm{~s}$, in both the theory of management and business practice, an accelerated development and implementation of multidimensional performance measurement systems has started (Bititci/Carrie/McDevitt 1997). Finally, to assess a company's long-term business success, an appropriate growth measurement system needs to be adapted.

The research design of this study is primarily determined by the objective view of business performance in the long run. Consequently, an adequate set of measures had to be adopted. The most basic indicators of company growth (decline) are positive (negative) changes in the number of employees, revenue, and total assets during the particular time-period. Based on that premise, for the dependent latent variable - business performance (in the long run), a very simple three-indicator measure was adopted. Those three indicators are:

- "Change in the Number of Employees" $\left(Y_{1}\right)$ - measuring increase (decrease) in the number of employees in three time-periods: 2005-2006, 2005-2010, and 2005-2015 (logarithmic transformation used):

$$
\begin{gathered}
Y_{1}^{i}=\frac{(\text { No. of Employees })_{i}-(\text { No. of Employees })_{2005}}{(\text { No. of Employees })_{2005}} ; \\
i=[2006,2010,2015]
\end{gathered}
$$

- "Change in the Revenue" $\left(\mathrm{Y}_{2}\right)$ - measuring revenue growth (decline) in three time-periods: 2005-2006, 2005-2010, and 2005-2015 (logarithmic transformation used):

$$
Y_{2}^{i}=\frac{(\text { Revenue })_{i}-(\text { Revenue })_{2005}}{(\text { Revenue })_{2005}} ; i=[2006,2010,2015]
$$

- "Change in the Total Assets" $\left(Y_{3}\right)$ - measuring total assets growth (decline) in three time-periods: 2005-2006, 2005-2010, and 2005-2015 (logarithmic transformation used):

$$
Y_{3}^{i}=\frac{(\text { Total Assets })_{i}-(\text { Total Assets })_{2005}}{(\text { Total Assets })_{2005}} ; i=[2006,2010,2015]
$$

For the monetary related variables, Revenue and Total Assets, a correction by inflation coefficient was made, so that all values are shown in BAM from 2006. 


\subsubsection{Independent Variables}

As can be clearly seen from Figure 1, the research design must ensure comparison between the following two groups of companies:

- Group 1 - companies that have not implemented any management innovation during the five-year period, from the year 2006 to the year $2010-n o n-$ innovative in management,

- Group 2 - companies that have implemented some management innovation during the five year period, from the year 2006 to the year 2010 -innovative in management.

Obviously, this is a simple case of a single non-metric independent variable "Innovativeness" $(G)$, which has two levels to differentiate between these two groups of companies.

In order to distinguish between these two groups an appropriate measure has been developed, which completely relies on the relevant literature on management innovation (Hamel 2006, 2007, 2012; Mol/Birkinshaw 2009; Birkinshaw 2010). Based on the list of important and noteworthy innovations in different areas of management (Mol/Birkinshaw 2007), a relevant selection of the significant and widespread management innovations (such as supply chain management, balanced scorecard, enterprise resource planning...) has been classified in four categories: Process, Strategy \& Performance, Customer \& Information, and People \& Structures. All surveyed companies were then instructed to point out the management innovations they have implemented during the period from the year 2006 to the year 2010 .

Based on the gathered data, companies were allocated to specific groups. If a particular company has implemented at least one new management practice, process or structure in two or more categories, during the period from the year 2006 to the year 2010, then it is assumed that the company is innovative in management (Group 2). All other companies are considered as non-innovative in management (during the specified time-period) and, therefore, assigned to Group 1.

The second independent variable - Time-period (TP), identifies three time-periods through which the dependent variable measurement was taken:

- Time-period 1 - initial time-period that lasts from the year 2005 to the year 2006,

- Time-period 2 - intermediate time-period that lasts from the year 2005 to the year 2010 ,

- Time-period 3 - final time-period that lasts from the year 2005 to the year 2015.

The initial time-period (Time-period 1) serves as an initial measurement, or as an equivalent to the short-term measurement period. Analogously, the intermedi- 
ate time-period (Time-period 2) serves as an equivalent to the mid-term measurement period, and final time-period (Time-period 3) serves as an equivalent to the long-term measurement period.

\subsection{Results}

As previously stated, a mixed design with two-way MANOVA was used to investigate the effect of management innovativeness on companies' performance during different time-periods. Subsequently, companies were classified into two groups - innovative and non-innovative, and three indicators were selected to measure the dependent variable - long-term business performance. Table 1 shows the means and standard deviations of all model indicator variables for both groups of independent variable $G$.

As can be seen from Table 1, there is a big discrepancy in the number of companies in the two groups, with the sample sizes of 106 and 28, for Group 1 and Group 2, respectively. Such a difference is expected, because the managers' focus, in general, is on technology/technical innovation and not on management innovation (Hamel 2007). However, since there are only three dependent variables in the model, these sample sizes provide for the identification of medium effect sizes with the required statistical power of 0.8 (Hair/Black/Babin/Anderson 2009).

Table 1. Descriptive statistics of indicator variables for groups of $G$

\begin{tabular}{|c|c|c|c|c|c|c|c|c|}
\hline & & & 200 & 006 & 200 & 010 & 200 & \\
\hline Indicators & Groups & $\mathbf{N}$ & Mean & $\begin{array}{l}\text { Std. } \\
\text { Dev. }\end{array}$ & Mean & $\begin{array}{l}\text { Std. } \\
\text { Dev. }\end{array}$ & Mean & $\begin{array}{l}\text { Std. } \\
\text { Dev. }\end{array}$ \\
\hline$Y_{1}$ & Group 1 & 106 & 0.144 & 0.336 & 0.435 & 0.805 & 0.621 & 1.601 \\
\hline (Change in the & Group 2 & 28 & 0.216 & 0.471 & 1.083 & 2.076 & 1.520 & 2.989 \\
\hline Employees) & Total & 134 & 0.159 & 0.368 & 0.570 & 1.207 & 0.809 & 1.993 \\
\hline$Y_{2}$ & Group 1 & 106 & 0.027 & 0.396 & 0.146 & 0.607 & 0.240 & 1.040 \\
\hline (Change in the & Group 2 & 28 & 0.159 & 0.957 & 1.346 & 4.133 & 2.841 & 8.683 \\
\hline Revenue) & Total & 134 & 0.054 & 0.559 & 0.396 & 2.000 & 0.784 & 4.158 \\
\hline$Y_{3}$ & Group 1 & 106 & 0.159 & 0.420 & 0.508 & 0.697 & 0.815 & 1.283 \\
\hline (Change in the & Group 2 & 28 & 0.128 & 0.419 & 1.368 & 2.364 & 2.275 & 4.298 \\
\hline Total Assets) & Total & 134 & 0.152 & 0.419 & 0.688 & 1.281 & 1.120 & 2.325 \\
\hline
\end{tabular}

\subsubsection{Assumptions}

To obtain reliable findings with the mixed design two-way MANOVA, the assumptions required for it must hold true. Thus, before the findings evaluation 
and discussion, a testing of these assumptions was conducted through the IBM ${ }^{\circledR}$ SPSS Statistics ${ }^{\circledR}$.

\section{Data type and independence of observations}

In this research design, all three indicators of the dependent variable (number of employees, revenue, total assets) are metric, while independent variables (innovativeness and time-period) are categorical, providing that data type assumption holds true. Independence of observations was provided to the extent possible by a random selection of the responding firms.

\section{Outliers and missing data}

Originally, there were 134 cases in the dataset, where twelve of them were outliers, which laid more than four standard deviations away from the mean value. These outliers would have a strong negative impact on the MANOVA results, as well as on the normality of the indicators, so appropriate remedy actions were taken (Tabachnick/Fidell 2007). Five cases were removed from the dataset and the other seven outlier values were reduced in such a way that they fall within the region of $\left(\bar{y}_{i}+2 \sigma, \bar{y}_{i}+4 \sigma\right)$.

All this remedy actions have resulted in a slight sample size decrease (from 134 to 129 cases), but there are no multivariate outliers in the sample, and the normality of the indicators was significantly improved (more specifically, outliers and normality after the data transformation). At the same time, the power of the test is preserved, since the sample size was almost intact.

There were no missing data in the sample, so in relation to this assumption no action of any type was taken.

Normality

All indicators in the dataset showed significant non-normality, thus the logarithmic transformation was used to remedy this violation. After transformation, all but five indicators showed a normal distribution. Since the MANOVA analysis is robust to modest violations of normality for the sample size of at least 20 in the smallest cell (Tabachnick/Fidell 2007), it can be considered that findings may not be severely affected. This violation can be further compensated by decreasing the $p$ value while testing the significance of MANOVA statistics (Verma 2016).

The means and standard errors of the transformed variables for both groups of independent variable $G$ are presented in Table 2. Graphical representation of the same data is displayed in Figure 2. 
Table 2. Means and standard errors for the transformed indicator variables for groups of $G$

\begin{tabular}{|c|c|c|c|c|}
\hline Measure & Innovativeness & Time-period & Mean & Std. Error \\
\hline \multirow{6}{*}{$\begin{array}{l}\tilde{Y}_{1} \\
\text { (Change in the Number } \\
\text { of Employees) }\end{array}$} & \multirow{3}{*}{$\begin{array}{l}\text { Non-innovative } \\
\text { (Group 1) }\end{array}$} & $2005-2006$ & -0.696 & 0.038 \\
\hline & & $2005-2010$ & 0.329 & 0.048 \\
\hline & & $2005-2015$ & 0.395 & 0.075 \\
\hline & \multirow{3}{*}{$\begin{array}{l}\text { Innovative } \\
\text { (Group 2) }\end{array}$} & $2005-2006$ & -0.645 & 0.076 \\
\hline & & $2005-2010$ & 0.595 & 0.096 \\
\hline & & $2005-2015$ & 0.755 & 0.149 \\
\hline \multirow{6}{*}{$\begin{array}{l}\tilde{Y}_{2} \\
\text { (Change in the Revenue) }\end{array}$} & \multirow{3}{*}{$\begin{array}{l}\text { Non-innovative } \\
\text { (Group 1) }\end{array}$} & $2005-2006$ & 0.217 & 0.027 \\
\hline & & $2005-2010$ & 0.340 & 0.043 \\
\hline & & $2005-2015$ & 0.108 & 0.084 \\
\hline & \multirow{3}{*}{$\begin{array}{l}\text { Innovative } \\
\text { (Group 2) }\end{array}$} & $2005-2006$ & 0.156 & 0.053 \\
\hline & & $2005-2010$ & 0.521 & 0.086 \\
\hline & & $2005-2015$ & 0.609 & 0.167 \\
\hline \multirow{6}{*}{$\begin{array}{l}\tilde{Y}_{3} \\
\text { (Change in the Total } \\
\text { Assets) }\end{array}$} & \multirow{3}{*}{$\begin{array}{l}\text { Non-innovative } \\
\text { (Group 1) }\end{array}$} & 2005-2006 & 0.099 & 0.026 \\
\hline & & $2005-2010$ & 0.039 & 0.063 \\
\hline & & $2005-2015$ & 0.526 & 0.067 \\
\hline & \multirow{3}{*}{$\begin{array}{l}\text { Innovative } \\
\text { (Group 2) }\end{array}$} & $2005-2006$ & 0.055 & 0.051 \\
\hline & & $2005-2010$ & 0.339 & 0.126 \\
\hline & & $2005-2015$ & 0.865 & 0.133 \\
\hline
\end{tabular}

Figure 2. Graphical display of marginal means of transformed performance indicators
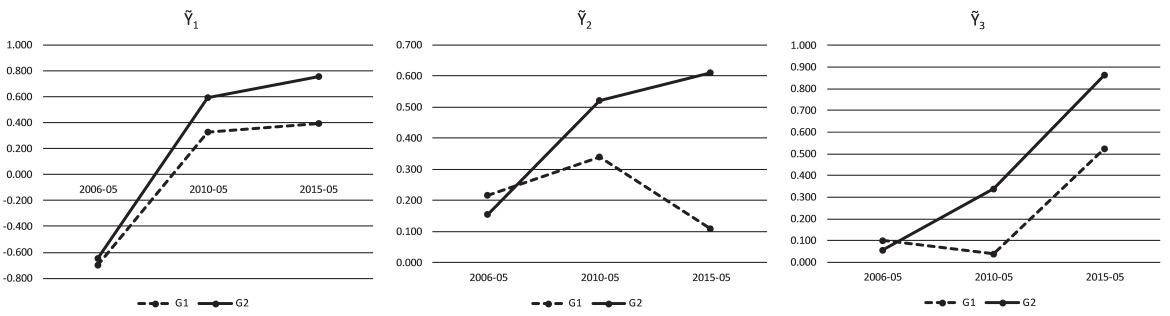

Homogeneity of variances and variance-covariance matrices

The equality of the variance-covariance matrices for all groups was checked using the Box's test. The obtained results from this test $[M=62.857, F(45,7008)$ $=1.204, p=0.165$ ] were not statistically significant at $p<0.001$, meaning that there were no difference between the two groups on all variables collectively. Therefore, the assumption of homogeneity of variance-covariance matrices was met.

The assumption of the homogeneity of variances was assessed by the Levene's test. This assumption was met $(p>0.05)$ for all but one indicator. Even though 
the mixed design research assumes the homogeneity of variances, this is a very slight violation, so it could be tolerated. However, because of this violation, the family-wise error must be strictly controlled.

Multicollinearity

For this type of research design, all indicators should be moderately correlated to each other for all cells, with correlation below 0.9 in order to avoid the multicollinearity (Verma 2016). Correlations between all indicators are higher than 0.3 and below the 0.9, except for the first time-period (2005-2006), where a slight deviation exists $-\operatorname{corr}\left(\tilde{Y}_{1}, \tilde{Y}_{3}\right)=0.144(<0.3)$. This means that multicollinearity does not exist, so this assumption was met.

\section{Sphericity}

The Mauchly's W test was used for testing the sphericity assumption. The chisquare statistics associated with Mauchly's W test was significant for all levels of the within-subject factor, so the sphericity assumption was not met. Thus, the Greenhouse-Geisser correction in the degrees of freedom should have been used.

\subsubsection{The MANOVA Model Estimation}

Since all assumptions were met or there exists an adequate compensation, the next step was to assess if significant differences exist for performance indicators across the two groups of companies through the three time-periods, first for all indicators combined and then for each of them individually.

The family-wise error rate was taken as $\alpha=0.05$ for the MANOVA test, while for the follow-up ANOVA tests for main effects, the inflated family-wise error was used as $\alpha=0.017(=0.05 / 3)$. Wilks' Lambda $(\lambda)$ was used as a multivariate test. Table 3 displays test results for the effect of innovativeness (between-subjects), time-period (within-subjects), and interaction between time-period and innovativeness on the three performance indicators.

As can be seen from Table 3, there exists a significant multivariate effect across the interaction between innovativeness and time-period [Wilks' $\lambda=0.855, F(6$, $122)=3.442, p=0.004]$, which is the most important test for this research design. Since this test was significant, a follow-up ANOVA for each performance indicator had been conducted (main effects).

The multivariate effect of innovativeness $(G)$ is not significant, irrespective of time-period [Wilks' $\lambda=0.958, F(3,125)=1.810, p=0.149$ ]. This means there is no difference in combined performance indicators between two different groups of companies (innovative and non-innovative). At the same time, the multivariate effect of time-period $(T P)$ is significant, irrespective of the companies' group [Wilks' $\lambda=0.109, F(6,122)=166.109, p<0.001$ ]. This finding 
points toward an increase in companies' business performance over time, which may be observed from Table 2 and, especially, from the diagrams displayed in Figure 2.

Table 3. Multivariate tests for group differences

\begin{tabular}{|l|l|r|r|r|r|r|r|r|}
\hline \multicolumn{2}{|c|}{ Effect } & Value & \multicolumn{1}{c|}{$\boldsymbol{F}$} & \multicolumn{1}{c|}{$\boldsymbol{d f 1}$} & \multicolumn{1}{c|}{$\boldsymbol{d f 2}$} & \multicolumn{1}{c|}{ Sig. } & \multicolumn{1}{c|}{$\boldsymbol{r}$} & Power \\
\hline \multirow{3}{*}{ Wilks' $\lambda$} & Intercept & 0.639 & 23.533 & 3 & 125 & 0.000 & 0.60 & 1.000 \\
\cline { 2 - 9 } & Innovativeness $(G)$ & 0.958 & 1.810 & 3 & 125 & 0.149 & 0.20 & 0.462 \\
\cline { 2 - 9 } & Time-period $(T P)$ & 0.109 & 166.109 & 6 & 122 & 0.000 & 0.94 & 1.000 \\
\cline { 2 - 9 } & Interaction $-T P \times G$ & 0.855 & 3.442 & 6 & 122 & 0.004 & 0.38 & 0.935 \\
\hline
\end{tabular}

Table 4 shows the repeated measure ANOVA test results for the interaction (TP $x G$ ) main effect on each of the performance indicators separately. Since the sphericity assumption has been violated, the Greenhouse-Geisser correction of degrees of freedom was used for all three performance indicators, as well as the inflated family-wise error $\alpha=0.017$.

Table 4. Repeated measures ANOVA results for the interaction (TP x G) - Main effect

\begin{tabular}{|lc|r|r|r|r|r|r|r|}
\hline Source & Measure & \multicolumn{1}{c|}{$\begin{array}{c}\text { s of } \\
\text { sq. }\end{array}$} & \multicolumn{1}{c|}{ df } & $\begin{array}{c}\text { Mean } \\
\text { sq. }\end{array}$ & $\mathbf{F}$ & Sig. & r & Pwr \\
\hline$T P \times G$ & $\tilde{Y}_{1}$ Greenhouse-Geisser & 1.038 & 1.474 & 0.705 & 3.439 & 0.049 & 0.16 & 0.551 \\
\hline & $\tilde{Y}_{2}$ Greenhouse-Geisser & 3.311 & 1.270 & 2.608 & 8.862 & $\mathbf{0 . 0 0 2}$ & 0.25 & 0.897 \\
\hline & $\tilde{Y}_{3}$ Greenhouse-Geisser & 1.846 & 1.598 & 1.155 & 6.448 & $\mathbf{0 . 0 0 4}$ & 0.22 & 0.847 \\
\hline Error & $\tilde{Y}_{1}$ Greenhouse-Geisser & 38.347 & 187.139 & 0.205 & & & & \\
\hline$(T P)$ & $\tilde{Y}_{2}$ Greenhouse-Geisser & 47.453 & 161.267 & 0.294 & & & & \\
\hline & $\tilde{Y}_{3}$ Greenhouse-Geisser & 36.367 & 202.984 & 0.179 & & & & \\
\hline
\end{tabular}

As can be seen from Table 4, the most important main effect for this research is that the interaction between time-period and innovativeness $(T P x G)$ is significant, at the level of 0.017 , for the effects of indicators $\tilde{Y}_{2}$ (Change in the Revenue) and $\tilde{Y}_{3}$ (Change in the Total Assets), and not significant on indicator $\tilde{Y}_{1}$ (Change in the Number of Employees). This means that the difference in business performance between the two groups of companies is primarily induced by the difference in indicators $\tilde{Y}_{2}$ and $\tilde{Y}_{3}$, and some underlying combination of the three performance indicators. To break down this interaction a further analysis of simple effects for each performance indicators was conducted.

The last step in the MANOVA model estimation procedure is the examination of simple effects for each performance indicator separately. These effects can be examined from Table 5, where simple effects of $G$ on different levels of $T P$ are shown, as well as from Figure 2, where interaction (TP $x G)$ charts for all three indicators are displayed. 
Table 5. Simple effects of $G$ within each level of TP

\begin{tabular}{|c|c|c|c|c|c|c|c|c|}
\hline Measure & Period & & $\Sigma$ of sq. & $d f$ & $\begin{array}{l}\text { Mean } \\
\text { sq. }\end{array}$ & $F$ & Sig. ${ }^{*}$ & $\mathbf{r}$ \\
\hline \multirow{6}{*}{$\begin{array}{l}\tilde{Y}_{1} \\
\text { (Change in } \\
\text { the Number } \\
\text { of Employees) }\end{array}$} & $2005-2006$ & Contrast & 0.055 & 1 & 0.055 & 0.368 & 0.545 & 0.06 \\
\hline & & Error & 19.023 & 127 & 0.150 & & & \\
\hline & $2005-2010$ & Contrast & 1.470 & 1 & 1.470 & 6.123 & 0.015 & 0.21 \\
\hline & & Error & 30.497 & 127 & 0.240 & & & \\
\hline & 2005-1015 & Contrast & 2.691 & 1 & 2.691 & 4.674 & 0.033 & 0.19 \\
\hline & & Error & 73.119 & 127 & 0.576 & & & \\
\hline \multirow{6}{*}{$\begin{array}{l}\tilde{Y}_{2} \\
\text { (Change in } \\
\text { the Revenue) }\end{array}$} & 2005-2006 & Contrast & 0.078 & 1 & 0.078 & 1.049 & 0.308 & 0.09 \\
\hline & & Error & 9.407 & 127 & 0.074 & & & \\
\hline & $2005-2010$ & Contrast & 0.673 & 1 & 0.673 & 3.505 & 0.063 & 0.16 \\
\hline & & Error & 24.376 & 127 & 0.192 & & & \\
\hline & $2005-1015$ & Contrast & 5.226 & 1 & 5.226 & 7.23 & 0.008 & 0.23 \\
\hline & & Error & 91.793 & 127 & 0.723 & & & \\
\hline \multirow{6}{*}{$\begin{array}{l}\tilde{Y}_{3} \\
\text { (Change in } \\
\text { the Total } \\
\text { Assets) }\end{array}$} & $2005-2006$ & Contrast & 0.040 & 1 & 0.040 & 0.581 & 0.447 & 0.07 \\
\hline & & Error & 8.755 & 127 & 0.069 & & & \\
\hline & $2005-2010$ & Contrast & 1.869 & 1 & 1.869 & 4.509 & 0.036 & 0.18 \\
\hline & & Error & 52.63 & 127 & 0.414 & & & \\
\hline & 2005-1015 & Contrast & 2.392 & 1 & 2.392 & 5.184 & 0.024 & 0.20 \\
\hline & & Error & 58.586 & 127 & 0.461 & & & \\
\hline
\end{tabular}

* - Bonferroni adjustments for multiple comparisons

Table 6. Estimated marginal means for interaction (TP x G) - pairwise comparisons

\begin{tabular}{|ll|r|r|r|}
\hline Measure & Period & \multicolumn{1}{c|}{$\begin{array}{c}\text { Mean difference } \\
\text { G2 - G1 }\end{array}$} & \multicolumn{1}{c|}{$\begin{array}{c}\text { Standard } \\
\text { Error }\end{array}$} & Sig. $^{*}$ \\
\hline $\begin{array}{l}\tilde{Y}_{1} \\
\text { (Change in the Number of } \\
\text { Employees) }\end{array}$ & $2005-2006$ & 0.052 & 0.085 & 0.545 \\
\cline { 2 - 5 } & $2005-2010$ & 0.266 & 0.108 & $\mathbf{0 . 0 1 5}$ \\
\cline { 2 - 5 } $\begin{array}{l}\tilde{Y}_{2} \\
\text { (Change in the Revenue) }\end{array}$ & $2005-1015$ & 0.360 & 0.167 & $\mathbf{0 . 0 3 3}$ \\
\cline { 2 - 6 } & $2005-2006$ & -0.061 & 0.060 & 0.308 \\
\hline $\begin{array}{l}\tilde{Y}_{3} \\
\text { (Change in the Total Assets) }\end{array}$ & $2005-2010$ & 0.180 & 0.096 & 0.063 \\
\cline { 2 - 6 } & $2005-1015$ & 0.502 & 0.187 & $\mathbf{0 . 0 0 8}$ \\
\cline { 2 - 6 } & $2005-2006$ & -0.044 & 0.058 & 0.447 \\
\hline
\end{tabular}

G1 - Non-innovative companies; G2 - Innovative companies; * - Bonferroni adjustments for multiple comparisons

As can be seen from Table 5, the simple contrasts for last time-period on each of the performance indicators are statistically significant $(p<0.05)$. These results 
are based on the estimated marginal means linearly independent pairwise comparisons (Table 6), where Bonferroni adjustment for multiple comparisons was used.

The results presented in Table 6, as well as the charts displayed in Figure 2, show that values of difference in the marginal means between the innovative (Group 2) and non-innovative companies (Group 1) are non-decreasing for all performance indicators.

These simple contrasts showed that there exist statistically significant differences, at the level of 0.05 , between innovative companies (Group 2) and noninnovative companies (Group 1) for all performance indicators $-\tilde{Y}_{l}$ (Change in the Number of Employees), $\tilde{Y}_{2}$ (Change in the Revenue), and $\tilde{Y}_{3}$ (Change in the Total Assets), in the long run. Furthermore, they also showed that this difference increase with time.

\subsubsection{Interpretation of the Results}

As previously stated, all assumptions for mixed design two-way MANOVA are met or there are appropriate corrections for their violation, so the results from the conducted analysis can be considered as reliable. Hence, a few insights about the relationship between management innovation and long-term business performance may be inferred and, consequently, some deeper understanding of management innovation phenomenon. Of course, all of that is under the conditions of the market and business environment in the Federation of Bosnia and Herzegovina.

The most important multivariate effect - that across the interaction between companies' innovativeness and time-periods, was statistically significant (Table $3)$. This finding tells us that there exists a difference in business performance over time between innovative and non-innovative groups, which supports the first hypothesis in a way that the rivalling null-hypothesis may be rejected. At the same time, having this effect significant, a follow up analysis has become meaningful.

The simple effect analysis results (Tables 5 and 6) revealed that the difference between innovative and non-innovative companies is positive and statistically significant for all performance indicators for the third time-period (2005-2015), and for performance indicators $\tilde{Y}_{1}$ and $\tilde{Y}_{3}$ for the second time-period (2005-2010). This finding, along with the significant multivariate interaction effect, fully supports the first hypothesis of this study.

Interaction diagrams (Figure 2) show that for innovative companies the average values of all performance indicators increase over time. For non-innovative companies, however, this trend varies a lot - either average values increase all the time $\left(\tilde{Y}_{l}\right)$ or increase and then decrease $\left(\tilde{Y}_{2}\right)$ or decrease and then increase 
$\left(\tilde{Y}_{3}\right)$. Furthermore, the difference between mean values of each performance indicator for innovative and non-innovative companies increases over time (Table 6). This means that performance superiority, indicated by combined long-term performance indicators $-\tilde{Y}_{1}, \tilde{Y}_{2}$, and $\tilde{Y}_{3}$, increase over time, which provides a full support for the second hypothesis of this study.

\subsection{Discussion}

The economic situation, as well as the overall business climate in Bosnia and Herzegovina are not really favourable for running the companies. In addition, the global financial crisis coincided with the research period, thus making the business conditions even worse. In such a harsh environment, managers must act fast and in an innovative way in order to properly address all business challenges. Consequently, it can be arguably said that the dire economic conditions propel managers to embrace innovation as the right strategy to follow. As the research data show (Table 1), companies that have adapted their management model to the crisis conditions, through a series of different management innovations, consistently outperform other companies in the long run.

The results obtained by testing the designed research model provide a full support for both research hypotheses. Such results go in favour of the basic reasoning of this study, which is that companies that are innovative in management achieve better business performance in the long run, which is a consequence of a sustainable competitive advantage created through an innovative management model. Therefore, investing time, efforts and all necessary resources of a company in management innovation activities is no longer a question of prestige or a carefully built company image, but a question of building and maintaining the company's core competencies. This propensity for innovation will have to be embedded in the managerial DNA of all business organizations (Hamel 2012).

Having both research hypotheses proven seems like a very strong support to the main study assertion about management innovation durability. However, looking at the effect size (Table 5) it can be seen that only about 5 per cent of variance in dependent variable (long-term business performance) is explained by the research model, that is by the companies' management innovativeness. Such a rather small effect means that some (or many) other variables have a similar or stronger impact on long-term business performance superiority, and that the impact of management innovation is not very significant. Similarly, a number of studies show that some other factors, which affect the management model, explain a (very) small portion of variance in company performance, too (Hill/Jones 2013).

Explaining or predicting company's success is a very difficult task, especially in the long run. Namely, long-term business performance, which can be considered as the main measure of long-term success, is reflected by changes in two or 
more states of one or more indicators (Neely 2007), and such changes are much harder to predict (explain) than the states themselves (Mol/Birkinshaw 2009). Furthermore, long-term business success, and for that matter long-term performance, cannot be explained as a function of one or, possibly, two factors. Rather, performance is characterized by complex functional dependence of several factors. Drawing a parallel with the relationship between human genotype and phenotype (Mukherjee 2016), the above mentioned functional interdependence can be written down as:

\section{Business Performance $=$ \\ $f$ (Management model, Environment, Triggers, Chance)}

In the above functional relation, the "Management model" argument represents all management practices, tools and structures that a particular company implements in order to organize and run its business. This argument is directly related to the management innovation concept and, accordingly, to the subject of this study. As can be seen from the stated relation, clearly and formally, management innovation is only one of the influential factors of company performance, and that fact is what limits the explanatory power of this argument.

The "Environment" argument represents company's business surroundings (Porter 1980, 1990) both at the industry level (industry dynamics, competition intensity, profitability...) and the national level (factor conditions, demand conditions, government policies...). In the same way as the "Management model", the "Environment" argument is just another influential factor of company performance, thus its explanatory power is rather limited, too. On the other side, a very specific argument is the "Chance", which represents the role that luck plays in determining the business performance (Porter 1990; Hill/Jones 2013). The presence of this argument does not mean one can just sit around and wait for stellar performance out of nothing by pure chance, but rather that luck acts as a catalyst for all other arguments, individually or in any combination.

Finally, the "Triggers" argument represents the events that cause notable changes in company's business outcome. Those can be some major strategic moves like entering new markets, going international, or divesting some business unit. However, for this study, much more important events are those that are related to the introduction of technological innovations. Namely, combined or synchronous adoption of technological and non-technological innovation has, arguably, a bigger and more positive effect on business performance than individual or sequential adoption of these two types of innovation (Damanpour et al. 2009; Volberda/Van den Bosh/Heij 2013; Damanpour 2014).

Based on the above reasoning, future research of the link between management innovation and business performance should be directed toward exploring the effects of combined technological and managerial innovation. Very likely, in 
such a way, the higher proportion of variance in (long-term) business performance would be explained by some future research models. That would also be the main recommendation for the future research on the topic. The results of such research will be useful both to academia and management practitioners the former to comprehend and explain the phenomenon of sustainable business success, and the latter to successfully run their companies in the long-run.

\subsubsection{Limitations of the Research}

There are several limitations that apply to this research. First, to start with design limitations, the study is focused on only one aspect of management innovation - those management innovations that are new to the company and not to the "state of art" (Mol/Birkinshaw 2009). Second, in order to keep the design simple and straight, only a small set of indicators was used and, consequently, a smaller portion of variance in dependent variable (long-term business performance) was explained. Hence, one of the recommendations for future research on the topic would be to seek out new indicators which would improve the measurement of the dependent variable and, possibly, the explanatory value of the design.

Finally, measurement of management innovativeness may be improved in a way that a finer differentiation between companies should be made. One preferred outcome from the improvement of this measurement model would be a clear distinguishing between companies that pursue different types of innovativeness. That would, undoubtedly, increase the complexity of the research design, but would also enable a deeper insight in the contribution of different innovation types to the company performance.

From a technical point of view, data analysis was conducted on a single sample whose size is just adequate for this research design. Consequently, no confirmation of the findings was done, neither with multiple samples nor with a single sample randomly split into two or more subsamples. In addition, data used in this study come from one country only, which has a very specific economic and political setting. This means that the obtained results may be specific to that particular context and could be generalized only for the population from which the sample was drawn. Future studies may remedy the above noted limitations by applying this research design to different datasets.

Last but not least, the issue of causality needs to be addressed. Even though MANOVA is primarily intended for experimental approach to the research, this quasi-experimental approach (survey research) is quite common in empirical research. The problem with this approach is that the researcher does not have full control over the research environment, so the unambiguous cause and effect relationship cannot be established. Specifically for this study, the issue comes down to whether the increase in business performance is a cause or effect of the increase in innovative activities. Nevertheless, there is strong support in theory 
that innovations contribute positively to company performance (see the Literature Review section), so it can be considered that the existing theory establishes the assumed causal order.

\section{Conclusion}

This study addresses the rarely explored consequences of management innovation for company performance in the long run. Based on the existing knowledge base and empirical studies on the topic of management innovation, efforts were directed toward making an appropriate research design, which could provide for testing the link between management innovation and long-term business performance. Accordingly, using a sample of companies from the Federation of Bosnia and Herzegovina, the developed set of hypotheses was tested.

The research results have undoubtedly shown that management innovation does produce a difference in companies' performance outcome in the long run. In other words, companies that are innovative in management achieve a better longterm business performance. Nonetheless, the results also showed that the effect size is rather small, meaning that management innovation explains but a small portion of variance in the long-term business performance. Management innovation has favourable consequences for a company's performance and success in general. This type of innovation is essential for contemporary companies to address all current and future business challenges. Moreover, in combination with technological innovation, management innovation can achieve its full potential for a maximum contribution to a company's competitive advantage. This line of reasoning is based on recent research works on the topic of management innovation (Damanpour 2014), which is further supported by the results of this study.

This research contributes to the body of knowledge related to management innovation by providing further insight into its effect on company's performance in the long run. In addition, it provides further support to the recommendation for studying the interdependent approach in adopting different innovation types.

\section{References}

Abrahamson, E. (1991): Managerial Fad and Fashions: The Diffusion and Rejection of Innovations, in: Academy of Management Review, 16, 3, 586-612.

Bezdrob, M./Šunje, A. (2012): Performance outcome of management innovation, in: Tipurić D./Dabić, M. (ed.): Management, Governance, and Entrepreneurship - New Perspectives and Challenges, Darwen: Access Press UK, 69-92.

Birkinshaw, J. (2010): Reinventing Management. San Francisco: Jossey-Bass.

Birkinshaw, J./Mol, M.J./Hamel, G. (2005): Management Innovation, in: Advanced Institute of Management Research, WP 021 [online]. Available at: https://papers.ssrn.com/s ol3/papers.cfm?abstract_id=1306981. [29.8.2017]. 
Birkinshaw, J./Mol, M.J. (2006): How Management Innovation Happens, in: MIT Sloan Management Review, 47, 4, 81-88.

Birkinshaw, J./Hamel, G./Mol, M.J. (2008): Management Innovation, in: Academy of Management Review, 33, 4, 825-845.

Bititci, U.S./Carrie, A.S./McDevitt, L. (1997): Integrated Performance Measurement Systems - A Development Guide, in: International Journal of Operations \& Production Management, 17, 5, 522-534.

Crossan, M.M./Apaydin, M. (2010): A Multi-Dimensional Framework of Organizational Innovation: A Systematic Review of the Literature, in: Journal of Management Studies, 47, 6, 1154-1191.

Damanpour, F. (1991): Organizational Innovation: A Meta-Analysis of Effects of Determinants and Moderators, in: Academy of Management Journal, 34, 3, 555-590.

Damanpour, F. (1992): Organizational Size and Innovation, in: Organization studies, 13, 3, 375-402.

Damanpour, F./Walker, R.M./Avellaneda, C.N. (2009): Combinative Effects of Innovation Types and Organizational Performance: A Longitudinal Study of Service Organizations, in: Journal of Management Studies, 46, 4, 650-675.

Damanpour, F./Aravind, D. (2012): Managerial Innovation: Conceptions, Processes, and Antecedents, in: Management and Organization Review, 8, 2, 423-454.

Damanpour, F. (2014): Footnotes to Research on Management Innovation, in: Organization studies, 35, 9, 1265-1285.

De Witt, B./Meyer, R. (2014): Strategy: An International Perspective. $5^{\text {th }}$ Revised Edition, Andover: Cengage Learning EMEA.

Drucker, P.F. (1974): Management: Tasks, Responsibilities, Practices. New York: Harper \& Row.

Gruber, W.H./Niles, J.S. (1972): Put Innovation in the Organization Structure, in: California Management Review, 14, 4, 29-35.

Gruber, W.H./Niles, J.S. (1974): How to Innovate in Management, in: Organizational Dynamics, 3, 2, 30-47.

Hair, J.F./Black, W.C./Babin, B.J./Anderson, R.E. (2009): Multivariate Data Analysis. $7^{\text {th }}$ Edition, Upper Saddle River: Prentice Hall.

Hamel, G. (2006): The Why, What, and How of Management Innovation, in: Harvard Business Review, 84, 2, 72-84.

Hamel, G. (2007): The Future of Management. Boston: Harvard Business School Press.

Hamel, G. (2012): What Matters Now: How to Win in a World of Relentless Change, Ferocious Competition, and Unstoppable Innovation. San Francisco: Jossey-Bass.

Helfat, C.E./Finkelstein, S./Mitchell, W./Peteraf, M./Singh, H./Teece, D./Winter, S.G. (2007): Dynamic Capabilities: Understanding Strategic Change in Organizations. New York: Wiley-Blackwell.

Hervas-Oliver, J-L./Ripoll-Sempere, F./Moll, C. (2016): Does Management Innovation Payoff in SMEs? Empirical Evidence for Spanish SMEs, in: Small Business Economics, 47, 2, 507-533.

Hill, C.W.L./Jones, G.R. (2013): Strategic Management: An Integrated Approach. 10 ${ }^{\text {th }}$ Edition, Mason: South-Western Cengage Learning. 
Klomp, L./van Leeuwen, G. (2001): Linking Innovation and Firm Performance: A New Approach, in: International Journal of the Economics of Business, 8, 3, 343-364.

Land, G. (1997): Grow or Die: The Unifying Principle of Transformation. Scottsdale: Leadership 2000 Inc.

Lebas, M./Euske, K. (2007): A conceptual and operational delineation of performance, in: Neely, A. (ed.): Business Performance Measurement: Unifying Theory and Integrating Practice, $2^{\text {nd }}$ Edition, Cambridge: Cambridge University Press, 125-139.

Mol, M.J./Birkinshaw, J. (2007): Giant Steps in Management: Innovations That Change the Way You Work. Harlow: Financial Times/Prentice Hall.

Mol, M.J./Birkinshaw, J. (2009): The Sources of Management Innovation: When Firms Introduce New Management Practices, in: Journal of Business Research, 62, 12, 1269-1280.

Mukherjee, S. (2016): The Gene: An Intimate History. New York: Scribner.

Neely, A. (2007): Business Performance Measurement: Unifying Theory and Integrating Practice. $2^{\text {nd }}$ Edition, Cambridge: Cambridge University Press.

Neely, A./Kennerley, M./Adams, C. (2007): Performance Measurement Frameworks: A Review, in: Neely, A. (ed.): Business Performance Measurement: Unifying Theory and Integrating Practice, $2^{\text {nd }}$ Edition, Cambridge: Cambridge University Press, 143-162.

Nieves, J. (2016): Outcomes of Management Innovation: An Empirical Analysis in the Services Industry, in: European Management Review, 13, 2, 125-136.

Porter, M.E. (1980): The Competitive Strategy. New York: The Free Press.

Porter, M.E. (1990): The Competitive Advantage of Nations. New York: The Free Press.

Samuelson, P.A./Nordhaus, W.D. (1995): Economics. 15 ${ }^{\text {th }}$ Edition, New York: McGrow-Hill.

Sapprasert, K./Clausen, T.H. (2012): Organizational Innovation and its Effects, in: Industrial and Corporate Change, 21, 5, 1283-1305.

Schumpeter, J.A. (1939): Business Cycles: A theoretical, historical and statistical analysis of the Capitalist process. New York: McGraw-Hill.

Shaw Solo, C. (1951): Innovation in the Capitalist Process: A Critique of the Schumpeterian Theory, in: Quarterly Journal of Economics, 65, 3, 417-428.

Spear, S./Bowen, H.K. (1999): Decoding the DNA of the Toyota Production System, in: Harvard Business Review, 77, 9/10, 96-106.

Stata, R. (1989): Organizational Learning - The Key to Management Innovation, in: MIT Sloan Management Review, 30, 3, 63-74.

Stock, R.M./Zaharias, N.A. (2011): Patterns and Performance Outcomes of Innovation Orientation, in: Journal of the Academy of Marketing Science, 39, 6, 870-888.

Tabachnick, B.G./Fidell, L.S. (2007): Using Multivariate Statistics. $5^{\text {th }}$ Edition. London: Pearson Education Inc.

Verma, J.P. (2016): Repeated Measures Design for Empirical Researchers. Hoboken: John Wiley \& Sons, Inc.

Volberda, H.M./Van den Bosh, F.A.J./Heij, C.V. (2013): Management Innovation: Management as Fertile Ground for Innovation, in: European Management Review, 10, 1, 1-15.

Walker, R.M./Damanpour, F./Devece, C.A. (2011): Management Innovation and Organizational Performance: The Mediating Effect of Performance Management, in: Journal of Public Administration Research and Theory, 21, 2, 367-386. 
Walker, R.M./Chen, J./Aravind, D. (2015): Management innovation and firm performance:

An integration of research findings, in: European Management Journal, 33, 5, 407-422.

Weihrich, H./Koontz, H. (1994): Management: A Global Perspective. $10^{\text {th }}$ Edition, New York:

McGraw-Hill Education.

\section{Production Controlling in the Context of Industry 4.0}

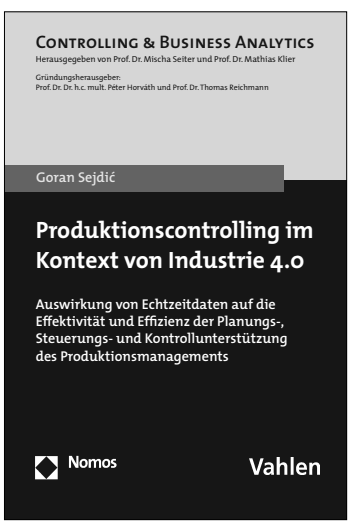

\section{Produktionscontrolling im Kontext von Industrie 4.0}

Auswirkung von Echtzeitdaten auf die Effektivität und Effizienz der Planungs-, Steuerungs- und Kontrollunterstützung des Produktionsmanagements

By Dr. Goran Sejdić 2019, approx. 250 pp., pb., approx. $€ 49.00$ ISBN 978-3-8487-5707-7

Publication date: approx. May 2019 nomos-shop.de/41121

In German language

This work develops a method with which not only the effectiveness and efficiency of production controlling in general but also the effect of realtime data on the effectiveness and efficiency of production controlling in particular can be studied.

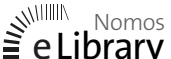 \\ www.nomos-elibrary.de}

To order please visit www.nomos-shop.de, send a fax to (+49)7221/2104-43 or contact your local bookstore. 